\title{
Building comprehensive narratives from dialogical encounters: A path in search of meanings
}

\section{Construindo narrativas compreensivas a partir de encontros dialógicos: um caminho em busca de significados}

\author{
Elizabeth Brown Vallim BRISOLA ${ }^{1}$ \\ Vera Engler CURY2 \\ Larry DAVIDSON ${ }^{3}$
}

\begin{abstract}
Phenomenological investigations are concerned with unfolding the nature of a phenomenon through the process of describing and understanding subjective lived experiences. The process through which this is accomplished varies according to the underlying philosophical concepts and specific methodological strategies adopted. A common means of achieving this objective is through hours-long interviews that are recorded and later transcribed and analyzed. The present article describes an alternative method that accesses the participants' experiences of a phenomenon through encounters with a researcher, who then uses dialogical data to develop comprehensive narratives. These are written in first person in order to grasp the participant's significant meanings based on what emerged during their encounter and its impact on the researcher. A narrative synthesis is then constructed in order to enable the phenomenological process of analysis to reach the structural elements based on all participants' experiences. Exemplary excerpts are presented in order to illustrate the process.
\end{abstract}

Keywords: Dialogical encounters; Narratives; Phenomenological research.

\section{Resumo}

Investigações fenomenológicas empenham-se em desvelar a natureza de um fenômeno por meio da descrição e compreensão de experiências vividas. Esse processo apresenta variações de acordo com os conceitos filosóficos subjacentes e as estratégias metodológicas adotadas. A forma habitual consiste na gravação de longas entrevistas que são posteriormente transcritas e analisadas. O presente artigo descreve um método alternativo para entrar em contato com as experiências dos participantes sobre determinado fenômeno, por meio de encontros dialógicos com o pesquisador. Este desenvolve narrativas compreensivas, escritas em primeira pessoa, com o propósito de captar os significados das experiências dos participantes a partir do impacto provocado pelos encontros vividos com eles sobre si mesmo. Uma narrativa síntese é, então, construída para dar prosseguimento ao processo de análise, a fim de revelar os elementos estruturais do fenômeno a partir das experiências de todos os participantes. Exemplos são apresentados para ilustrar o processo.

Palavras-chave: Encontros dialógicos; Narrativas; Pesquisa fenomenológica.

$\checkmark \nabla \nabla$

${ }^{1}$ Pontifícia Universidade Católica de Campinas, Grupo de Pesquisa "Atenção Psicológica em Instituições: Prevenção e Intervenção".

2 Pontifícia Universidade Católica de Campinas, Pró Reitoria de Pesquisa e Pós-Graduação de Extensão e Assuntos Comunitários. Av. John Boyd Dunlop, s/n., Jardim Ipaussurama, 13060-904, Campinas, SP, Brasil. Correspondência para/Correspondence to: V. E. CURY. E-mail: <vency2985@gmail.com>.

${ }^{3}$ Yale University, Yale School of Medicine, Yale Program for Recovery and Community Health. New Haven, CT, United States. 
Phenomenological studies are concerned with discovering the nature of a phenomenon through the process of describing and understanding subjective day-to-day, or lived experiences (Davidson, 2003). It studies the lifeworld, the realm of pre-reflective experience (Husserl, 1954/1970) asking: what is this experience like? The process of answering this question varies according to the underlying philosophical concepts and specific methodological strategies adopted by the researcher (Willig, 2013).

A common means of reaching this objective is through hours-long interviews that are recorded and later transcribed, analyzed, and synthesized through general structural summaries. This process, although rendering rich and useful results, often focuses on what participants say and how the researcher makes sense of what they said and not as much on how participants make sense of these experiences themselves (Weber, 1986). But exploring the first-person perspective through an implicit second-perspective (i.e., that of the researcher) runs the risk of robbing the original language of its "power, clarity, and depth, even its meaning" (p.71). It also opens up the possibility of untested misunderstandings emerging across cultural, social, and even interpersonal life worlds.

The "Psychological Attention in Institutions: Prevention and Intervention" Research Group at the Graduate Psychology Program of the Pontifical Catholic University in Campinas, Brazil, has been developing an alternative, dialogical approach to phenomenological research for the past 10 years (Miranda \& Cury, 2010; Mozena \& Cury, 2010; Palmieri-Perches \& Cury, 2013; Souza \& Cury, 2015; Vasconcellos \& Cury, in press; Zini \& Cury, 2014). In this research group, studies are conducted using comprehensive narratives, which are constructed to apprehend and interpret the lived experiences of participants, but through embracing rather than overlooking the researcher's experience of being with them. This unique method has been inspired by Husserl's (1931/2012) descriptive phenomenology, and the central role that empathy come to understand another person's point of view on her own experiences (Husserl, 1950/1999). In this way, this approach also borrows from the work of Rogers (1980) on eliciting personal narratives through the unconditional acceptance of the validity of another person's point of view (without making epistemological claims).

The use of narratives as an instrument of research is not new. They have been utilized in various areas of knowledge (history, anthropology, sociology, psychology) with distinct objectives (Granato, Corbett, \& Aiello-Vaisberg, 2011; Larsson \& Sjöblom, 2010), presenting themselves as an effective way of studying lived experiences and an appropriate way to access their meanings (Granato \& Aiello-Vaisberg, 2013; Kramp, 2004). They also have been used within the context of descriptive phenomenological research (e.g., Sells, Topor, \& Davidson, 2004), but in this case they remain a product of the researcher's own reflections on each participant's experience. According to Granato et al. (2011), writing a narrative is in itself a process of elaborating one's own experiences.

The present article describes the construction process and philosophical foundations of comprehensive narratives developed through dialogical means by the Research Group mentioned above. Also, exemplary excerpts of individual comprehensive narratives are presented and an example of a narrative synthesis, which encompasses the meanings of the lived experiences across a group of participants who have certain kinds of experiences in common.

\section{Comprehensive narratives}

Our research studies begin with dialogical encounters with participants, presupposing that knowledge grows from being immersed in intersubjectivity (Szymanski \& Cury, 2004). Being in a relationship is an intrinsic part of the research since both participant and researcher are necessarily part of the study and a source of discovery and knowledge. Therefore, truly being with the 
participants is paramount in our studies and also consistent with Husserl's (1931/2012) suggestion of "going back to the things themselves", since there is an effort to understand what an experience means from the participant's viewpoint, not through the researcher's filters, presuppositions, and preconceptions (Davidson, 2003).

In this way, conversations with participants are intended to be much more than an interview. That is why they are called encounters: to highlight the importance of "being with" the participants, deeply listening and exchanging ideas; rather than simply trying to obtain information from them. The intention is to seek closeness, to be emotionally touched by them and to touch them, not simply to use them as an instrument of research (Amatuzzi, 2006). These encounters are called dialogical (from Greek dialogikos), emphasizing a two-way road in which both researcher and participant exchange ideas and thoughts, dialoguing, conversing. They are purposefully not recorded since we are not "gathering data" but immersing ourselves in a relationship, aiming to listen carefully, opening up to oneself and to the participant, to the moment, and to being together. This "togetherness" opens doors to meanings of the person's lived experiences that might have been overlooked in a more onesided interview approach.

A tape recorder may give a certain sense of security ("I've got it all") but may distract the researcher from being entirely open to another person. The absence of a tape recorder changes how we are present, conferring the privilege of being more aware, more "plugged into" the person we are with and to the present moment. When we try to be ourselves, accepting of others and empathically present, as Rogers $(1977,1980)$ described, our subjectivity becomes a pathway for disclosure, a bridge to the lived experience of others (Cury, 2007), revealing an encounter and the meanings therein. But you may ask: who's lived experience is revealed? The participant's or the researcher's? We suggest both. Because as we open ourselves to the experience of others, our own lived experience at that moment becomes the other's, as we endeavor to "live" their experience "as if" they were our own. The researcher's openness to her own and to the participant's experience also serves as an invitation to the participant to openly explore her own experiences. This openness and intrinsic motivation is essential, enabling the meanings embedded in the experiences to emerge in the encounter.

Immediately following and while still under the impact of the encounter, the researcher then begins writing a comprehensive narrative, communicating this encounter, including the impressions, feelings and thoughts that emerged from her and the participant's lived experience from their time together. The focus is on the experiences and their meanings, rather than on facts. These narratives value the conversation and reveal aspects of the experience lived by both parties. It does not focus on content but on the comprehension of the senses of the experiences lived in that encounter between both persons.

Writing such a narrative requires going through an internal process of gradual exploration that unrolls from the impact the encounter had on the researcher. The narrative flows from the meeting of subjectivities, from the researcher's attitude of being sincerely open and with the participant; meanings flow as she turns to the phenomenon as it arrives in her consciousness. While writing, the researcher purposefully seeks to be close to the participant's world and her lived experience, not trying to analyze, conclude or judge. However, if a clear idea or interpretation does come to mind, it is added.

Comprehensive narratives are built gradually, as days go by and a natural process of deepening occurs. Researchers find themselves in a position of looking back and rescuing what they lived, in a rigorous (not random or arbitrary) manner, gradually exploring the experience they had with the participant (Mozena \& Cury, 2010; Oliveira \& Cury, 2016). This happens in stages, through the natural course of consciousness and the retrieving of memories. At first, the 
narrative is more descriptive, as researchers write down everything they remember from that lived experience. After reading this first, more descriptive narrative, researchers are impacted by the reading and narrate once more, this time with a different gaze, seeing new meanings, seeing more clearly. They do this again, until there are no more new impressions or meanings.

An important part of this process is reading the narratives to a select group and then listening to colleagues' comments. It is important, though, for this to occur in a respectful atmosphere, with a group of people intent on understanding the researcher's intentions, facilitating a better comprehension and perception of the participant's experience; not evaluating, but empathic to the participant's experience and her encounter with the researcher. This has worked as a validity check, as well as an opportunity to listen to impressions the narrative had on others. Since the narrative construction is a lonesome endeavor and, of course, subject to faults, reading a comprehensive narrative to a group enables the researcher to check if she was, indeed, able to respect both her own feelings as well as those of the participant.

When the researcher meets the second participant and others thereafter, she has already been changed (i.e., "contaminated") by the first, and is further changed in the course of each encounter as the experiential process evolves. Not only is the encounter an agent of change but the researcher also benefits from this process, understanding the phenomenon more clearly each time (Moustakas, 1994).

To illustrate this methodological approach, we've selected a few paragraphs from two comprehensive narratives of a study about the experience of mothers singing to their infants (Brisola, 2017) ${ }^{4}$. At the end of each excerpt, in parenthesis, is what might be written down on the borders, after the narrative is finished and read to the research group, as preparation for the next step, which is the building of a narrative synthesis.

\section{Exemplary excerpt: encounter with Maria}

I had a pleasant meeting with Maria, a young communicative lady that welcomed me to her apartment, surrounded by her family: 6 month-old Ivone, her husband, a small furry dog - which she called "my son" - and a cat. Her mother would have been there, too, but being a holiday, she was travelling [context] (p.74).

It was quite apparent to me - and Maria herself said so at the end of our conversation - that her singing habits were not evident to her, at first. "Because it's just "something you do". As our conversation moved on it became clearer to us: when, what and how she sang and also what it meant to her [the experience of singing is not readily available but as we converse it becomes clearer] (p.75).

During our conversation Maria also noticed she sings during routine activities, using known melodies but making up words according to the circumstances. "The words are ridiculous!" she emphasizes, "I simply describe what's happening. If I'm changing her, it's about pee, poop, diapers... I also do this when we're in the pool, during meals, in the car... but nothing rhymes. It simply reflects the moment."

Maria wanted me to understand that it wasn't something pretty, aesthetically pleasing. "It's not about beauty", I say

"No, there's no beauty, or rhyme... That's

${ }^{4}$ The excerpts were taken from the original text, available at: <http://tede.bibliotecadigital.puc-campinas.edu.br:8080/jspui/handle/ tede/951>. 
not why I do it..." - then silence. I'm imagining Maria asking herself: then why do I do it? Why do I sing? (p.76).

"It's not for Ivone that I sing..." - she starts "I'm thinking about this right now... I think she doesn't even notice; it probably doesn't even matter if I'm singing or talking... It's more for myself... a creative event"

"You feel creative?"

"Exactly...... I use all my tools"

This was a discovery to her, and we explored this discovery a little more. Then she added: "It's wonderful! I'm whole, completely involved in the situation" - and at this moment there seemed to be a "click". Her focus changed. It was no longer all about singing to her daughter. Now she was thinking about what it was like for her when she sang to her daughter [singing to her daughter is a creative moment; she feels she "uses all her tools"] (p.77).

Exemplary excerpt: encounter with Alice

When I arrived at her house, the three of us (Allison, her 18 month-old and I) sat on the living room rug and, for a moment, I thought our encounter was going to end up just being a visit - with no research - but 2 hours zoomed by and in the midst of blocks, games, colored pencils and crying, we did explore her experience of singing to her daughter [context] (p.93).

Sometimes her daughter asks her to sing a specific melody. She sees a bird and wants to hear the bird song, she sees a TV character and asks for the song. When she asks for one, two, three songs, fine. But when she continues asking, Allison turns her over to Daniela's father. "There are times that I just can't! I'm in the kitchen and I can't stop what I'm doing just to sing to her" - because Daniela wants all her attention, she has to stop cooking to sing. Sometimes she and her husband are having an important conversation in the car when
Daniela asks for a song but they don't want to stop just to fill in her demand. It's hard! "And - something else: It's difficult to sing for obligation. It's impossible! How do you sing when you don't want to, when you want to do something else?" [singing or not singing to her infant also means learning how to balance wishes: her own and her daughter's] (p.95).

\section{The narrative synthesis}

After comprehensive narratives are written for all participants, they are re-read, notes are taken, and a narrative synthesis is written, taking the necessary time to understand clearly the participants' experiences through their common qualities and themes. The question we ask is: "What does all of this tell me about the experience of this phenomenon?"

At this time we step back and try to comprehend the participants' experiences from "the outside", as psychologists, looking at a bigger picture. While the comprehensive narratives demand a movement of closeness to the participant's experience, through empathy, the narrative synthesis represents a deepening of the phenomenon in search of meanings present in the experiences seen as a whole. We are looking for the structure of that human experience (Amatuzzi, 2011) and it is through the very nature of experience - of being temporal, directed and "meaning-bestowing" (Davidson, 2003) - that the researcher is able to identify what is relevant and essential to the phenomenon. Husserl referred to this process as free imaginary variation used in order to distinguish the essential from the incidental (Finlay, 2009).

Therefore, as a researcher writes a narrative synthesis she focuses not on the participants' biographies but on what the participants as a group share in regard to the phenomenon of interest. The following is an example of the narrative synthesis from the same study about mother's experience of singing to infants (Brisola, 2017, p.117, our translation): 
Loud and clear, mothers said singing is communicating with their infants - on a deeper level. It is saying much more than words can express, hugging them with sound, filling the air around them with emotion and intention, while giving of themselves. Whether it be at home at bedtime or while driving the car, when mothers cannot hold their crying children, singing enables them to reach for them without hands, and allows them to feel connected, close, without necessarily touching.

They also pointed out that singing means bonding with their infants. It requires them to be truly present for and in relationship with them, figuring out what is happening between them, building a bridge, a connection. It involves reaching out, "stepping beyond themselves", with a desire to interact with their infant. As mothers sing, they share the moment with their infant. By living that moment together, their relationship develops and their bond deepens. Each one is attentive to the other. The infant pays close attention to the mother's song and the mother is especially attuned to the babies' reactions.

Singing also alters the humor of both mother and infant, affecting them emotionally and changing their emotional state. During difficult moments, especially if the infant is crying, singing usually calms them. During playful moments singing motivates, and cheers. Singing is also a strategy mothers use to get to know their infant. In each situation, as they sing to their infants and watch their reactions, mothers absorb information about their infant. They choose a song, sing, and observe. This allows them to learn to adapt their singing to each situation and each new phase. The choice of song, the way in which the mother sings it, and the ways in which she alters both song and delivery depending on the infant's response, gives mothers insight into their infant's present mood and preferences. Observing these interactions and the changes that take place through the months allow mothers to get to know their infants more intimately.

During the first few months, mothers try singing without knowing for certain whether it will work and which songs and moments are best. It's harder for them to evaluate the impact their songs have on their tiny infants. As time passes, however, and the babies grow and give more feedback, expressing their desires more clearly, and asking their mothers to sing certain songs, or to stop singing, the mothers adapt. This dynamic exchange of love, information, and preference between mother and child increases understanding, and strengthens their bond.

Mothers also described singing as an effective tool that enables them to inform, distract, comfort, and deal with their daily tasks and challenges. It helps the mother, during both difficult and playful moments, to get the baby's attention and accomplish a task, or overcome a challenge. At first, mothers are unsure, but as they sing and succeed in their tasks, this gives them a sense of accomplishment and confidence.

As mothers sing, they also pass on information and values. Through song, mothers share of themselves: they reveal who they are and what they believe in. Through their choices of songs, and the ways in which they sing them, they share their life, their story, thoughts, ideas, beliefs, language and culture. Singing the songs with which they grew up also links them to memories and emotions of past experiences and family stories.

Singing is a creative means of expression. Often mothers sing their own versions of songs, making up words and changing melodies. Sometimes they create entirely original songs expressing in their own 
particular ways, with their own unique voices, their inner thoughts and feelings.

Singing is also a subjective way of actualizing experiences. Mothers express what they are living at the moment with their voices, through song. Their choice of song makes sense at the moment, expresses and represents in words and sounds, their thoughts, perceptions, emotions, and/or frustrations. The songs become part of that moment, "glued" to the present activities, place, emotion, and relationship. The ability to express their experience through singing depends on how comfortable they are with their own voices. If they are at ease singing, this happens naturally, without any thought. When they are more self-conscious of their voice, it is harder to do, does not feel natural at all, and is used less.

At the end of our research studies, through the process of constructing the comprehensive and narrative syntheses, we arrive at the constituent elements of the phenomenon's structure. So, even though the individual participant's experiences are specific, the group's lived experiences enable us to bring to light the essence of the phenomenon as a human manifestation. If we are able to describe this structure with precision, it can be applied to all participants and to other people beyond them - within a certain cultural historical context. This can be understood, in a sense, as a way to generalize by means of deepening understanding of a phenomenon, not with concern for continuity.

\section{Final Considerations}

This article aimed to describe the use of comprehensive narratives in research studies as a means of discovering the nature of a phenomenon by describing and understanding subjective dayto-day experiences through dialogical encounters. Comprehensive narratives are constructed as a means to comprehend someone else's experience as she lives it through the researcher's active involvement in a dialogical encounter with the participant. It's uniqueness lies in its seeking to purposefully comprehend the participant's experience of the phenomena through her own experiences with them.

Researcher and participant's experiences are not separated, since both were part of the encounter. The comprehensive narrative includes this blending since the researcher is embedded in the participant's emotions, memories, perceptions and feelings and the participant, on the other hand, is also present, indirectly, embedded in the researcher's emotions, memories, perceptions and feelings. So it does not seek a subject-object dichotomy but presents meanings that emerge as "my-our" meanings.

Comprehensive narratives are a means by which the researcher gradually comes nearer to a phenomenon (eidetic reduction). They are also the result of this process, as each narrative represents the meaningful elements that emerge from the analysis of the lived experiences of the participant, shared by the researcher in a dialogical encounter.

This result enables the researcher to analyze and describe the experience of the phenomenon as a whole, in a new light, seen through the narrative synthesis. It is true that there is some risk involved as the researcher makes herself available to explore the participants' experiences in such an open way - and this we accept -, but we also believe there is great value in taking this risk as it moves her towards a kind of serendipity; giving her a different view of the experience of a phenomenon, opening a pathway to creativity, enabling her to see and describe it beyond the already existent and/or prevailing view of human experiences.

We realize the communication of an encounter with a participant usually does not purposefully include the researcher's own feelings, impressions and perceptions, and this can be seen as undesirable from the perspective of positivist research. However, when the results of this inclusion are examined, one can see the richness of meanings present in the encounter and perceive 
how this way of narrating encloses the vitality of the process of the encounter. The richness of the lived experience is not lost, nor are the subjective and intersubjective nuances characteristic to significant human relations. What we give up through this method in terms of a presumed but questionable neutrality, we gain through a shared understanding that is arrived at, over time, between researcher and participants' experiences.

\section{Contributors}

All authors contributed in the conception and final draft of this article.

\section{References}

Amatuzzi, M. M. (2006). A subjetividade e sua pesquisa. Memorandum, 10, 93-97.

Amatuzzi, M. M. (2011). Pesquisa fenomenológica em Psicologia. In M. A. T. Bruns \& A. F. Holanda (Orgs.), Psicologia e fenomenologia: reflexões e perspectivas. Campinas: Alínea.

Brisola, E. B. V. (2017). A experiência de cantar para bebês: um estudo fenomenológico com mães (Tese de doutorado não-publicada). Pontifícia Universidade Católica de Campinas. Retrieved April 12, 2017, from http://tede.bibliotecadigital.puc-campinas.edu. br:8080/jspui/handle/tede/951

Cury, V. E. (2007). Práticas psicológicas clínicas em instituições: um estudo sobre a narrativa com estratégia de pesquisa. In Primeiro Simpósio Internacional de Psicanálise e Fenomenologia. I Jornada de Pesquisa em Psicanálise e Fenomenologia do Laboratório de Psicologia Clínica Social, Pontifícia Universidade Católica de Campinas, Campinas, pp.20-30.

Davidson, L. (2003). Living outside mental illness: Qualitative studies of recovery in schizophrenia. New York: New York University Press.

Finlay, L. (2009). Debating phenomenological research methods. Phenomenology \& Practice, 3(1), 6-25.

Granato, T. M. M., \& Aiello-Vaisberg, T. M. J. (2013). Narrativas interativas sobre o cuidado materno e seus sentidos afetivo-emocionais. Psicologia Clínica, 25(1), 17-35.

Granato, T. M. M., Corbett, E., \& Aiello-Vaisberg, T. M. (2011). Narrativa interativa e psicanálise. Psicologia
Husserl, E. (2012). Ideas: General introduction to pure phenomenology. London: Routledge Classics. (Original work published 1931).

Husserl, E. (1970). The crisis of European sciences and transcendental phenomenology: An introduction to phenomenological philosophy. Evanston: Northwestern University Press. (Original work published 1954).

Husserl, E. (1999). Cartesian meditations: An introduction to phenomenology. Kluwer: Academic Publishers. (Original work published 1950).

Kramp, M. K. (2004). Exploring life and experience through narrative inquiry. In K. deMarrais \& S. D. Lapan (Eds.), Foundations for research: Methods of inquiry in education and the social sciences (pp.103121). Mahwah: Lawrence Erlbaum Associates.

Larsson, S., \& Sjöblom, Y. (2010). Perspectives on narrative methods in social work research. International Journal of Social Welfare, 19(3), 272280.

Miranda, R. M. R., \& Cury, V. E. (2010). Dançar o adolescer: estudo fenomenológico com um grupo de dança de rua em uma escolar. Paidéia, 20(47), 391-400.

Moustakas, C. (1994). Phenomenological research methods. California: Sage.

Mozena, H., \& Cury, V. E. (2010). Plantão psicológico em um serviço de assistência judiciária. Memorandum, 19, 65-78.

Oliveira, A. E. G., \& Cury, V. E. (2016). Cuidar em oncologia: uma experiência para além do sofrimento. Memorandum, 31, 237-258.

Palmieri-Perches, T. H., \& Cury, V. E. (2013). Plantão psicológico em hospital e o processo de mudança psicológica. Psicologia: Teoria e Pesquisa, 29(3), 313-320.

Rogers, C. R. (1977). A pessoa como centro. São Paulo: EPU.

Rogers, C. R. (1980). A way of being. Boston: Houghton Mifflin Company.

Sells, D., Topor, A., \& Davidson, L. (2004). Generating coherence out of chaos: Examples of the utility of empathic bridges in phenomenological research. Journal or Phenomenological Research, 35(2), 253271.

Souza, G. G., \& Cury, V. E. (2015). A experiência de estudantes sobre a atenção psicológica disponibilizada na universidade: um estudo fenomenológico. Memorandum, 28, 221-239.

Szymanski, H., \& Cury, V. E. (2004). A pesquisa intervenção em psicologia da educação e clínica: 
Pesquisa e prática psicológica. Estudos de Psicologia (Natal), 9(2), 355-364.

Vasconcellos, T. P., \& Cury, V. E. (2017). Atenção psicológica em situações extremas: compreendendo a experiência de psicólogos. Psicologia: Ciência e Profissão, 37(2), 475-488.

Weber, S. J. (1986). The nature of interviewing. Phenomenology and Pedagogy, 4(2), 65-72.

Willig, C. (2013). Introduction to qualitative research in
Psychology. Berkshire: Open University Press.

Zini, R. L. \& Cury, V. E. (2014). Acolhimento como prática psicológica no contexto de um Centro de Atenção Psicossocial em álcool e drogas. Memorandum, 27, 39-60.

Received: May 11, 2017

Approved: May 25, 2017 